FULL RESEARCH ARTICLE

\title{
The Explicit Integration of Species Conceptual Models and Species Distribution Models as a Best Practice for Systematic Conservation Planning in California
}

\author{
MONICA D. PARISI ${ }^{1 *}$ AND STEVEN E. GRECO ${ }^{1}$ \\ ${ }^{1}$ Department of Human Ecology - Landscape Architecture and Environmental Design, One \\ Shields Avenue, Davis, CA, 95616, USA
}

*Corresponding Author: mdparisi@ucdavis.edu

Natural Community Conservation Plans (NCCPs) represent the most powerful tool in statute for regional and systematic conservation planning for species at risk in California. This study examines the use of species conceptual models (SCMs) and species distribution models (SDMs) in such planning. Eighteen Natural Community Conservation Plans (NCCPs) were analyzed to determine if or how explicit connections were made between both types of models for a covered species and key components of its conservation strategy. Results indicate plans were strong in the use of SDMs, however, each deferred preparing or using SCMs to later management and monitoring phases. A more effective best planning practice for developing a conservation strategy is to explicitly integrate SCMs and SDMs during plan preparation.

Key words: endangered species, habitat conservation planning, Natural Community Conservation Planning (NCCP), species conceptual models, species distribution models

This is a study of the explicit and effective integration of species models into the planning processes of Natural Community Conservation Plans (NCCPs). As discussed herein, NCCPs are California's most powerful tool in statute for species conservation on a regional scale, with a higher standard for conservation than federal Habitat Conservation Plans (HCPs). In statute, NCCPs (California Fish \& G. Code $\S 2800$ et seq.) are an alternative to the project-by-project incidental take permitting process (Fish \& G. Code $\S 2081$ ) under the California Endangered Species Act (CESA). Such systematic and regional conservation planning is a critical ongoing need for the state and identifying "best practices" for all aspects of creating these plans is also an ongoing need. California has more than 2,000 plant species and more than 400 animal species that are considered to be at risk - meaning they are already state or federally listed as threatened or endangered or are at risk for becoming so (CDFW 2020a). The state's population is near 40 million and is expected to reach 45 million by the year 2035 (CDOF 2019).

Species models serve to gather the collective scientific knowledge of a species (Franklin 2009). Species account models (SAMs) are verbal accounts, yet they provide 
conceptual information such life history, habitat use, geographic range, distribution, threats, and population trends and so may be considered a form of modeling (Andelman et al. 2001). Management-oriented species conceptual models (SCMs), in graph form, clarify assumptions regarding a species' relationship to ecosystem components, stressors, and its response to potential management actions (Atkinson et al. 2004; Hopkins 2004). They also identify remaining uncertainties, key to hypothesis testing in an adaptive management and monitoring context. SCMs provide a bridge between the goals and objectives of a conservation plan and the conservation measures or management actions assumed necessary for achieving them and thus preparing them at the time a conservation plan is being written would be a best practice.

Explicitness in the development and use of species distribution models (SDMs) in conservation planning, particularly reserve design, would also be a best practice. The design of a reserve network is inherently spatial. SDMs provide spatial data on both known occurrences of a species as well as environmental variables thought to predict its occurrence. They also provide the rule base linking species occurrences to environmental variables (Franklin 2009). Explicitly disclosing rules and assumptions for mapping the predicted distribution of a species allows a user to both replicate a model and evaluate uncertainty in the prediction.

SAMs, SCMs and SDMs are communication tools, for stakeholders in the present and future. Over the lifetime of a plan, often 50 years or more, they can serve as a marker for future planners on the knowledge and assumptions guiding scientists and planners during the time at which a plan was approved.

Regional conservation planning is a tool for resolving potential conflicts between economic development (e.g., urbanization, agriculture) and threatened and endangered (listed) species, especially in biologically rich areas of the state that face high levels of growth and development (Atkinson et al. 2004). State and federal wildlife agencies in California have two primary statutes to accomplish species conservation - state Natural Community Conservation Plans (NCCPs) under California Fish and Game Code Section 2800 et seq. and federal Habitat Conservation Plans (HCPs) under the Endangered Species Act Section 10(a)(1)(B). These plans are intended to establish large reserve networks of permanently protected lands and long-term programs designed to conserve, mitigate for, and manage species legally "covered" by a plan while they allow compatible and appropriate development (Presley 2011). In California, an HCP can be implemented without an NCCP. However, all NCCPs are joint state and federal NCCP/HCPs, although hereafter they will be referred to as NCCPs. NCCPs in California may also be thought of as systematic conservation plans, the term "systematic conservation planning" having come from the seminal and highly cited work of the same name published in Nature by Christopher Margules and Robert Pressey (2000).

NCCPs may, in fact, be among the best examples of government-sponsored systematic conservation planning. Both NCCPs and HCPs provide conservation benefits beyond that of traditional approaches to endangered species conservation, which allow limited "incidental take" of species in exchange for habitat mitigation actions or offsets, often on a project-byproject basis (McKenney and Kiesecker 2010:174). This practice results in uncoordinated or piecemeal mitigation, far less effective than a coordinated, regional approach (Underwood 2010). NCCPs and HCPs provide coordinated mitigation and conservation actions that can result in larger blocks of higher quality and more connected habitats (Noss et al. 1997). Underwood (2010) demonstrated the effectiveness of this approach by comparing two large areas of San Diego County and finding that the portion with a multispecies NCCP/HCP had implemented 5-10 times more area for conservation of rare species than the portion practicing project-by-project or piecemeal mitigation. 
Beyond this, NCCPs are subject to an even higher standard for conservation than HCPs. To approve an HCP under the federal Endangered Species Act (16 USC $\S \S 1531-1544)$, the federal government must find that the taking of a species by a proposed project will not "appreciably reduce the likelihood of the survival and recovery of the species in the wild" (Section 10(a)(1)(B)(iv). By legislative intent, this finding is treated as equivalent to the language in Section 7(a)(2) - that a proposed project "... is not likely to jeopardize the continued existence of any endangered species or threatened species or result in the destruction or adverse modification of habitat" for the species. (See USFWS 2007 for example of equivalence language.) Effectively the standard is one of "no jeopardy" (Pollak 2001).

To approve an NCCP under California's Endangered Species Act (Fish \& G. Code $\S \S$ 2050-2089), the state government must find that "the development of reserve systems and conservation measures in the plan area provides, as needed for the conservation of species: ...the establishment of ...one or more reserves or other measures that provide equivalent conservation of Covered Species within the Plan Area and linkages between them and adjacent habitat areas outside the Plan Area" (Section 2820(a)(4)(B)). "Conservation" means "to use, and the use of, methods and procedures within the plan area that are necessary to bring any covered species to the point at which the measures provided pursuant to Chapter 1.5 (commencing with Section 2050) [The California Endangered Species Act] are not necessary" (Section 2805(d)). Requiring that a species be brought to the point of no longer requiring protection under the California Endangered Species Act is effectively a standard of recovery (Hopkins 2004; Presley 2011).

Thus, NCCPs are mandated to provide both recovery and habitat connectivity beyond plan boundaries for covered species, a powerful combination for the conservation of a species across its entire geographic range. Greco (2020) examined the mix of conservation standards across the geographic range of the federally and state-listed threatened giant garter snake (Thamnophis gigas) in California, finding only $14 \%$ of the range to be subject to an NCCP recovery standard and concluding that the variation in standards could have significant implications for recovery.

In this study, we examined the integration of species conceptual models and spatial models in the NCCP planning process (see Table 1 for a typology of models used in NCCPs). Often such models are included as appendices in NCCPs, but it is not always clear if and how they are used in the planning process. Specifically, we looked at how managementoriented species conceptual models (SCMs) and species distribution models (SDMs) are currently used in NCCPs - to guide biological goals and objectives, adaptive management and monitoring, and reserve design (see Fig. 1). Calls in the literature for explicitness in how models translate into conservation strategies and reserve designs come from Atkinson et al. (2004), Franklin et al. (2011), Guisan et al. (2013), and Tulloch et al. (2016). Specifically regarding SDMs, researchers have shown how the vast majority of research focuses on methods rather than implementation in the context of systematic conservation planning, implying that research on the explicit connections between SDMs and reserve design strategies is rare (Mair et al. 2018, Guisan et al. 2013). We assessed past and current practice regarding model integration (i.e., SAM, SCM, SDM) for systematic conservation planning throughout California.

We examined four central research questions, presented here with some key background information related to each question. First, what is the level of modelling done in the planning phase of an NCCP and do NCCPs prepare SCMs and SDMs during this phase? All NCCPs are in one of two phases: planning or implementation. In the planning 
Table 1. Typology of models used in NCCPs. According to Andelman et al. (2001), verbal accounts, mathematical formulae, and graphical diagrams are all structural variations of conceptual models. The conceptual model of interest here is a "management-oriented" species conceptual model (SCM). The spatial model of interest is a species distribution model (SDM).

\begin{tabular}{|c|c|c|c|}
\hline $\begin{array}{l}\text { Model Used } \\
\text { in NCCP }\end{array}$ & $\begin{array}{l}\text { Model Type } \\
\text { and Struc- } \\
\text { ture }\end{array}$ & $\begin{array}{l}\text { Alternate Terminology } \\
\text { for Model Structure }\end{array}$ & Model Inputs in NCCPs \\
\hline $\begin{array}{l}\text { Species Ac- } \\
\text { count Model } \\
(\text { SAM) }\end{array}$ & $\begin{array}{l}\text { Concep- } \\
\text { tual model: } \\
\text { verbal } \\
\text { (text-based) } \\
\text { account }\end{array}$ & $\begin{array}{l}\text { Species account } \\
\text { Ecological account } \\
\text { Species profile }\end{array}$ & $\begin{array}{l}\text { Legal status } \\
\text { Species description } \\
\text { Life history } \\
\text { Habitat associations } \\
\text { Geographic range } \\
\text { Home range or territory size } \\
\text { Distribution of occurrences in the plan } \\
\text { area } \\
\text { Threats } \\
\text { Population trends } \\
\text { Abundance estimates }\end{array}$ \\
\hline $\begin{array}{l}\text { Manage- } \\
\text { ment- } \\
\text { oriented } \\
\text { Species } \\
\text { Concep- } \\
\text { tual Model } \\
\text { (SCM) }\end{array}$ & $\begin{array}{l}\text { Concep- } \\
\text { tual model: } \\
\text { graphical } \\
\text { diagram }\end{array}$ & $\begin{array}{l}\text { Influence diagram } \\
\text { (Clemen 2001) } \\
\text { Conceptual diagram } \\
\text { (Goodwin and Wright } \\
\text { 1991) } \\
\text { Envirogram } \\
\text { (Andrewartha and } \\
\text { Birch 1984, James et } \\
\text { al. 1997) } \\
\text { Causal web } \\
\text { (Andelman et al. 2001) }\end{array}$ & $\begin{array}{l}\text { Measurable aspects of response (e.g. } \\
\text { habitat quality, patch occupancy, popula- } \\
\text { tion size) } \\
\text { Anthropogenic threats } \\
\text { Natural drivers } \\
\text { Management actions } \\
\text { Critical uncertainties }\end{array}$ \\
\hline
\end{tabular}

$\begin{array}{lll}\begin{array}{l}\text { Species } \\ \text { Distribu- } \\ \text { tion Model } \\ \text { (SDM), }\end{array} & \begin{array}{l}\text { Spatial } \\ \text { model: } \\ \text { distribution } \\ \text { map }\end{array} & \begin{array}{l}\text { Species distribution } \\ \text { model } \\ \text { (Franklin 2009) }\end{array} \\ \begin{array}{l}\text { using } \\ \text { discrete or }\end{array} & & \begin{array}{l}\text { Index of habitat suit- } \\ \text { ability or potential } \\ \text { continuous }\end{array} \\ \text { variables } & & \begin{array}{l}\text { occupancy (Barrows et } \\ \text { al. 2005) }\end{array}\end{array}$

Mapped occurrences or population locations

Classified (expert opinion) suitiable habitat - mapped as discrete polygons in vector format (if habitat features can be mapped)

Or

Environmental variables that correlate with species presence - mapped as a composite of continuous variables in raster format 
Table 1 continuted

\begin{tabular}{|c|c|c|c|}
\hline $\begin{array}{l}\text { Model Used } \\
\text { in NCCP }\end{array}$ & $\begin{array}{l}\text { Model Type } \\
\text { and Struc- } \\
\text { ture }\end{array}$ & $\begin{array}{l}\text { Alternate Terminology } \\
\text { for Model Structure }\end{array}$ & Model Inputs in NCCPs \\
\hline $\begin{array}{l}\text { Population } \\
\text { Viabil- } \\
\text { ity Analysis } \\
\text { (PVA), } \\
\text { depending } \\
\text { on available } \\
\text { data }\end{array}$ & $\begin{array}{l}\text { Conceptual } \\
\text { model: } \\
\text { mathemati- } \\
\text { cal formula }\end{array}$ & $\begin{array}{l}\text { Count-based popula- } \\
\text { tion viability analysis } \\
\text { (Santa Clara Valley } \\
\text { Habitat Plan 2012) } \\
\text { Count-based extinction } \\
\text { analysis (Morris et al. } \\
\text { 1999) }\end{array}$ & $\begin{array}{l}\text { Known numbers of adults } \\
\text { Population growth rates } \\
\text { Reproductive rates }\end{array}$ \\
\hline $\begin{array}{l}\text { Spatial PVA } \\
\text { (SPVA), } \\
\text { depending } \\
\text { on available } \\
\text { data }\end{array}$ & $\begin{array}{l}\text { Spatial mod- } \\
\text { el: spatially- } \\
\text { explicit } \\
\text { movement } \\
\text { model with } \\
\text { population } \\
\text { size and de- } \\
\text { mography }\end{array}$ & $\begin{array}{l}\text { Individual model } \\
\text { Occupancy map } \\
\text { Population projection } \\
\text { (size and demography) } \\
\text { (Schumaker } 1998, \\
2010 \text { ) }\end{array}$ & $\begin{array}{l}\text { SDM (with habitat suitability) } \\
\text { PVA parameters } \\
\text { Movement parameters }\end{array}$ \\
\hline
\end{tabular}

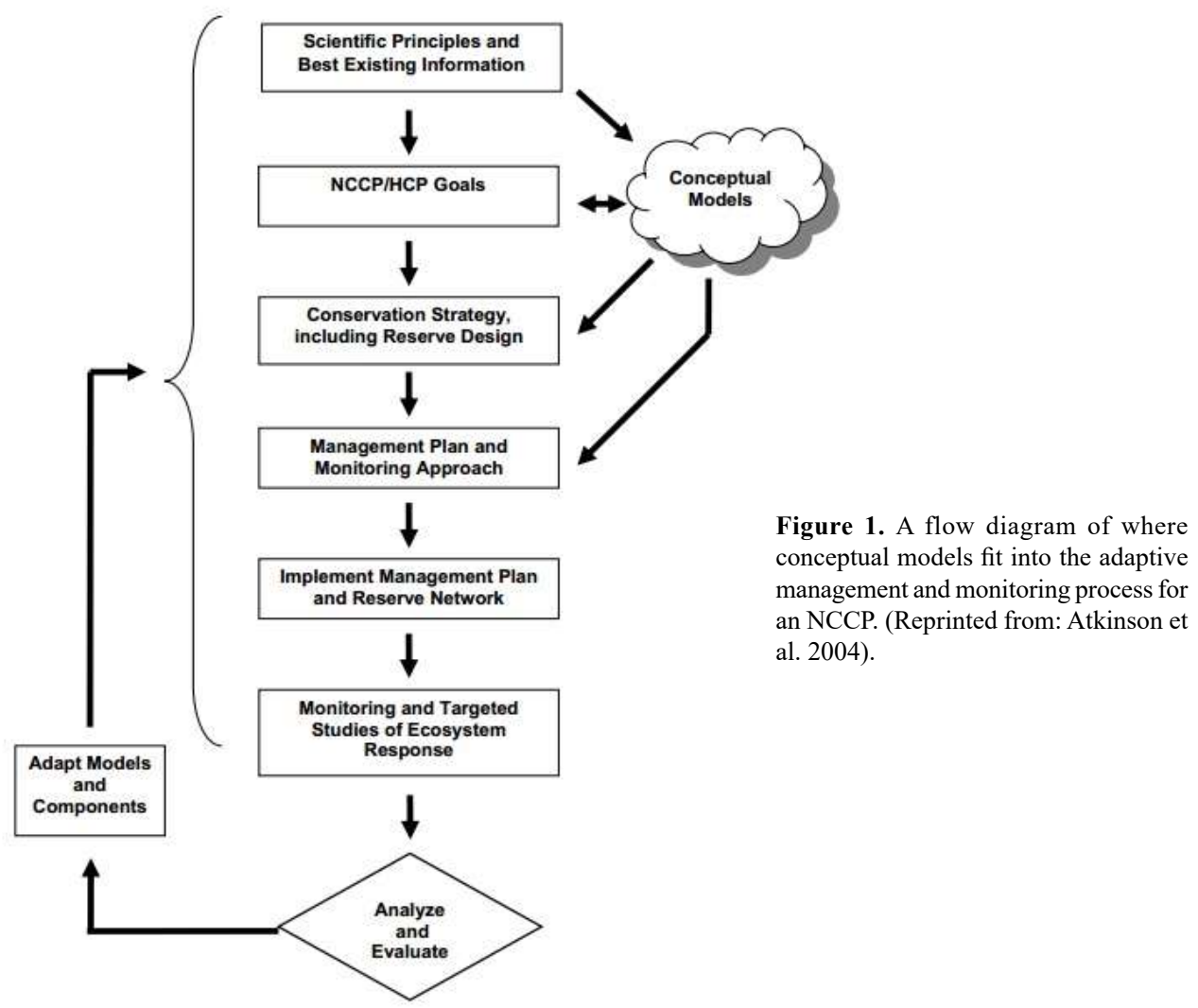


phase, an Enrollment Agreement or Planning Agreement has been signed by the permittee organizations and the state and federal wildlife agencies who will approve and permit the plans. As the plan is being developed, one or more administrative drafts may be produced internally before a draft is prepared for public review (Presley 2011). A core component of each NCCP is the conservation strategy, consisting of both the biological goals, objectives and conservation measures for the plan and a strategy for reserve design (Hopkins 2004). In the implementation phase, a plan has been approved and permitted and progress on the conservation strategy, such as acquisition of reserve lands, is actively underway.

The second research question is: are there explicit connections between the SCMs and the proposed adaptive management and monitoring program for each plan and, if so, how are they made? Beginning with the NCCP Act of 2003 each plan is required to contain an adaptive management and monitoring program (Atkinson et al. 2004). "Adaptive management" as defined in the NCCP Act "means to use the results of new information gathered through the monitoring program of the plan and from other sources to adjust management strategies and practices to assist in providing for the conservation of covered species" (NCCPA 2003).

This leads to our third research question: are there explicit connections between SCMs and the biological goals and objectives of each plan and, if so, how are they made? Goals, objectives, and conservation measures differ across plans in how they are used. Generally, however, goals are broad statements of desired outcomes that set the direction for an NCCP (e.g., conservation for a covered species in perpetuity), objectives are specific and measurable statements detailing how each goal can be achieved (e.g., a specified quantity of acres of some specific habitat type for a covered species) and conservation measures describe actions (e.g., acquire land in fee title). The term "conditions for coverage" is also sometimes used in the biological goals and objectives section of an NCCP to describe specific actions that must be taken for a species to be considered conserved and thus eligible for coverage under a plan.

Our final research question is: are there explicit connections between SDMs and the reserve design of each plan and, if so, how are they made? For the purposes of this study, the reserve design is defined to include both the measurable reserve acreage commitments in the biological goals and objectives and the spatial design of the reserve system for the entire plan area. As stated previously, NCCPs must provide a connected reserve system, with linkages between reserves inside the plan area and to adjacent habitat areas outside of the plan area (NCCPA 2003).

\section{METHODS}

The primary methodology used to explore and answer these questions was a keyword search of planning documents from 18 NCCPs in California that are either approved or in public draft form (Table 2). Nineteen NCCPs met this initial set of criteria, but one was dropped, the San Diego MSCP La Mesa Subarea Plan. The plan included only a brief statement describing its consistency to a programmatic NCCP, but otherwise contained none of the necessary elements to stand on its own as an NCCP. Of the remaining 18 plans, 15 have been approved and permitted and three are in public draft form, generally the final stage before public comments are reviewed and the plan is finalized and submitted to the state and federal wildlife agencies. Approved and permitted plans that are considered "Subarea Plans" to larger programmatic NCCPs were treated as unique plans. Programmatic NCCPs serve as "umbrella" plans. They do not receive permits and were not included as unique plans. However, they were considered as contributors of conservation analyses and modeling to 
Table 2. NCCP/HCPs in California presented in order of permit year or public draft year. Plans with a permit year are approved and in the implementation phase. Those with a public draft year are still in the planning phase.

\begin{tabular}{|c|c|c|c|c|}
\hline $\begin{array}{l}\text { Plan } \\
\#\end{array}$ & Approved and Permitted NCCP/HCPs & $\begin{array}{l}\text { Permit } \\
\text { Year }\end{array}$ & $\begin{array}{l}\text { NCCP Act } \\
\text { Version }\end{array}$ & $\begin{array}{l}\text { Scientific Advisor } \\
\text { Report }\end{array}$ \\
\hline 1 & San Diego Gas \& Electric & 1995 & 1991 & $\mathrm{n} / \mathrm{a}$ \\
\hline 2 & $\begin{array}{l}\text { County of Orange Central and Coastal } \\
\text { Subregion }\end{array}$ & 1996 & 1991 & $\mathrm{n} / \mathrm{a}$ \\
\hline 3 & $\begin{array}{l}\text { San Diego Multiple Species Conservation } \\
\text { Program (MSCP) Poway Subarea Plan }\end{array}$ & 1996 & 1991 & $\mathrm{n} / \mathrm{a}$ \\
\hline 4 & Kern Water Bank & 1997 & 1991 & $\mathrm{n} / \mathrm{a}$ \\
\hline 5 & San Diego MSCP City Subarea Plan & 1997 & 1991 & $\mathrm{n} / \mathrm{a}$ \\
\hline 6 & San Diego MSCP County Subarea Plan & 1998 & 1991 & $\mathrm{n} / \mathrm{a}$ \\
\hline 7 & $\begin{array}{l}\text { San Diego Multiple Habitat Conservation } \\
\text { Program (MHCP) Carslbad Subarea Plan }\end{array}$ & 2004 & 2001 & $\mathrm{n} / \mathrm{a}$ \\
\hline 8 & $\begin{array}{l}\text { Western Riverside Multi-Species Habitat } \\
\text { Conservation Plan (MSHCP) }\end{array}$ & 2004 & 2001 & $\mathrm{n} / \mathrm{a}$ \\
\hline 9 & $\begin{array}{l}\text { San Diego MSCP Chula Vista Subarea } \\
\text { Plan }\end{array}$ & 2005 & 2001 & $\mathrm{n} / \mathrm{a}$ \\
\hline 10 & East Contra Costa County & 2007 & 2003 & $\begin{array}{l}\text { Huntsinger et al. } \\
\text { (2003) }\end{array}$ \\
\hline 11 & $\begin{array}{l}\text { Coachella Valley Multiple Species Habi- } \\
\text { tat Conservation Plan (MSHCP) }\end{array}$ & 2008 & 2003 & Noss et al. (2001) \\
\hline 12 & San Diego County Water Authority & 2011 & 2003 & Rahn et al. (2008) \\
\hline 13 & Santa Clara Valley Habitat Plan & 2013 & 2003 & Spencer et al. (2006a) \\
\hline 14 & Orange County Transportation Authority & 2017 & 2003 & Rahn et al. (2011) \\
\hline \multirow[t]{2}{*}{15} & Yolo & 2019 & 2003 & Spencer et al. (2006b) \\
\hline & NCCP/HCPs in Public Draft Form & $\begin{array}{l}\text { Draft } \\
\text { Year }\end{array}$ & $\begin{array}{l}\text { NCCP Act } \\
\text { Version }\end{array}$ & $\begin{array}{l}\text { Scientific Advisor } \\
\text { Report }\end{array}$ \\
\hline 16 & Rancho Palos Verdes & 2018 & 2001 & $\mathrm{n} / \mathrm{a}$ \\
\hline 17 & Butte Regional Conservation Plan & 2019 & 2003 & Spencer et al. (2007) \\
\hline 18 & Placer County Conservation Plan & 2019 & 2003 & Brussard et al. (2004) \\
\hline
\end{tabular}


their subarea plans. All documents were publicly available as downloads from the websites of organizations serving as lead entities for the plans. A lead entity is generally a local government with land use planning authority, but it is not required to be so; regional authorities for water and transportation and private companies also undertake NCCPs (Hopkins 2004).

To address the first question regarding the level of modelling done in the planning phase of an NCCP, we searched each plan document using model names, model types, and alternate terms for model structure as keywords, entries in columns 1-3 of Table 1, respectively. The goal was to determine which of the model inputs (Column 4 entries) were present for species in a plan. The criteria for including model inputs as present are listed in Table 3. Model inputs were considered present if they were included for one or more species in a plan. They were also considered present if, in the case of subarea plans, direct reference was made to a species model in a programmatic NCCP. Of the six subarea plans, three relied wholly on species models produced for a programmatic NCCP and three both referenced models in a programmatic NCCP and included models for species in the subarea plan that were not included in the programmatic NCCP.

Table 3. Criteria for including model inputs as present in NCCPs

Model Inputs Criteria for Including Model Inputs as Present

\section{Species Account Model (SAM)}

Legal status

listing status as threatened or endangered under the California or federal Endangered Species Acts or rare under the California Native Plant Protection Act (FGC $\S \S 1900-1913$ ) inclusion on any administrative watch lists such as California Species of Special Concern

Species description

Life history

Habitat associations

Geographic range

Home range or territory size

Distribution of occurrences in the plan area

Threats

Population trends physical description, growth habit in the case of plants, and/or any level of taxonomic information

pattern of survival, life cycle, and reproduction events for a species for terrestrial wildlife species, habitat types, natural community types, or landcover types known to be suitable for a species meeting one or more life history requirements; for fish, stream reaches or water bodies with the proper conditions, such as temperature or flow rate or connectivity, to support one or more stages of a species' life history; for plants, inclusion of plant associations, soil type, hydrology, slope, or elevation

description and/or map of the limits of distribution globally, in North America or in California

for terrestrial wildlife species, reference to the distance an individual travels in meeting life history requirements; for species that are also territorial, reference to the average territory size for an individual, or a range of sizes depending on habitat conditions or gender

general description of population locations, often in the absence of surveys for the entire plan area

anthropogenic threats such as habitat loss or fragmentation, exotic species introduction, uncontrolled grazing, pollution, pesticide use, or noise disturbance

globally, in North America, in California, or in the plan area (if known); located through keyword searches on "trend", "population", "declining", "stable", and "increasing" 
Table 3 continuted

Model Inputs Criteria for Including Model Inputs as Present
Abundance estimates globally, in North America, in California, or in the plan area (if known), expressed as a range of population size or as a density estimate

Measurable aspects of re- Identification of variables for measuring the response of natural sponse communities, species or populations to management actions such as habitat quality, patch occupancy or population size, respectively

\section{Management- oriented Species Conceptual Model (SCM)}

Anthropogenic threats

threats such as habitat loss or fragmentation, exotic species introduction, uncontrolled grazing, pollution, pesticide use, or noise disturbance expressed as management issues in a conceptual diagram

Natural drivers drivers of change such as fire or hydrologic regimes directly connected to response variables in a conceptual diagram

Management actions mitigating actions directly connected to anthropogenic threats in a conceptual diagram

Critical uncertainties outstanding research questions for completing or updating a conceptual diagram

\section{Species Distribution Model (SDM), using discrete or continuous variables}

Mapped occurrences or population locations

Classified (expert opinion) suitiable habitat - mapped as discrete polygons in vector format (if habitat features can be mapped)

Or

Environmental variables that correlate with species presence - mapped as a composite of continuous variables in raster format

\section{Population Viability Analysis (PVA), depending on available data}

Known numbers of adults count-based or other methods of determining the number of adults

Population growth rates

occurrences presented as points in vector format in a GIS, either as maps in a plan document or available digitally as Geographic Information Systems (GIS) data

for terrestrial wildlife species, habitat types, natural community types, or landcover types known to be suitable for a species meeting one or more life history requirements, sometimes incorporating a minimum habitat patch size; for fish, stream reaches or water bodies with the proper conditions, such as temperature or flow rate or connectivity, to support one or more stages of a species' life history; for plants, inclusion of plant associations, soil type, hydrology, slope, or elevation (no instances found)

calculated rate based on a ratio between number of adults in any given year and number of adults one year later 
Table 3 continuted

\section{Model Inputs}

Reproductive rates

\section{Criteria for Including Model Inputs as Present}

\author{
fecundity, based on survival and fertility rates
}

\section{Spatial PVA (SPVA), depending on available data}

$\begin{array}{ll}\text { SDM (with habitat suitabil- } & \text { one of more of the SDM components listed above } \\ \text { ity) } & \text { one or more of the PVA components listed above } \\ \text { PVA parameters } & \begin{array}{l}\text { one or more spatial components of a PVA that affect habitat suit- } \\ \text { ability such as connectivity of habitat on a landscape or dispersal } \\ \text { ability of a species }\end{array}\end{array}$

To find explicit connections between the SCMs and the proposed adaptive management and monitoring program, our second question, we conducted a keyword search in the adaptive management and monitoring chapter of each plan for direct reference to the name and location of the species models in the documents for that plan. Only one plan was found to contain SCMs, so to determine intent to create SCMs among the remaining plans, we also searched for "concept" and "model." The search for explicit connections between SCMs and biological goals and objectives, our third question, was also limited because only one plan was found to contain SCMs. Therefore, to see how any level of species modeling may be influencing biological goals and objectives in the remaining plans, we looked at connections between the one SAM component that is in common with an SCM, namely, threats. "Threat" was used as a keyword in the search, as were "enhance" and "restore," action words found among biological goals and objectives for reducing or mitigating threats.

Finally, to research explicit connections between SDMs and reserve design, we looked in two locations within each plan. First, for connections to reserve acreage commitments, we searched the biological goals and objectives section for direct reference to the name and location of the SDMs in the documents for that plan. If this yielded no results, the keywords "model," "occurrence," and "occupied" were used to query for the components of an SDM. Second, for connections between the SDMs and the reserve design strategy for a plan, we employed several keywords that lead to descriptions of how SDMs may be used together, all of which can be found among the collection of planning documents: "criteria," "principle," "concept," "rule," "consideration," “design," "assembly," "synthesis," and "process."

\section{RESULTS}

Results for the level of modeling done in the planning phase of each NCCP are presented in Fig. 2. All 18 NCCPs contained the full suite of components for text-based SAMs. Only one NCCP prepared SCMs for its covered species in the planning phase (Plan \#18 of Table 2). Regarding SDMs, 17 of the 18 plans (94\%) contained maps of known occurrences for each covered species. Fifteen plans or $83 \%$ also presented expert-based habitat suitability maps for each covered species as discrete polygons in a vector-based GIS, wherein each mapped polygon represents one habitat type on the ground modeled as suitable for a species and contains a single habitat suitability value. No plans presented habitat suitability maps as a composite of continuous environmental variables in a raster-based GIS, wherein each 


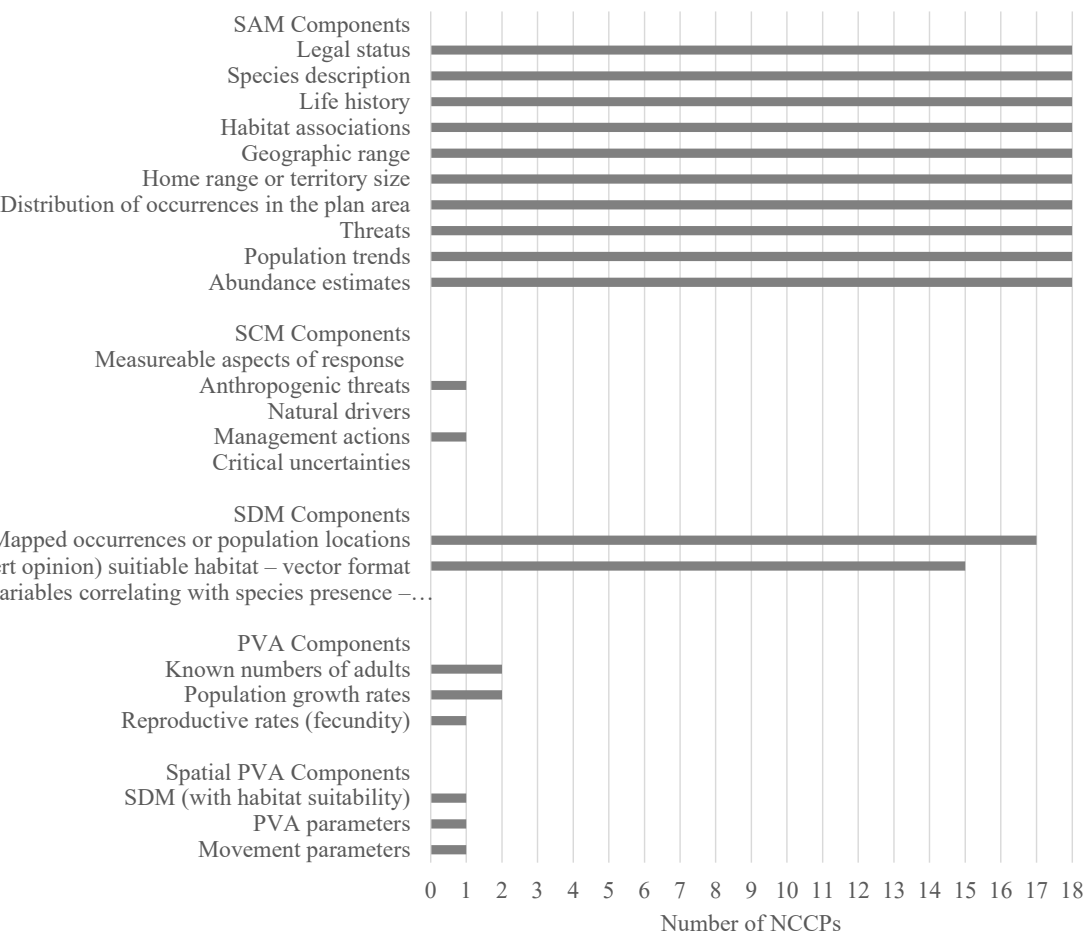

Figure 2. The model components and levels of species modeling found among existing NCCPs.

cell in a pixelated mapped surface has a habitat suitability value representing the summed value of layers of environmental variables for that cell on the ground, creating a "surface" of habitat suitability that is continuous. (See Chang 2019 for a full comparison of vector and raster data formats in GIS.) Just two plans (\#7, \#13) contained some components of Population Viability Analysis (PVA) species models and, in each case, for a single species only. One of these two plans (\#7) also had components of a spatial PVA.

Results for explicit connections between the SCMs and the proposed adaptive management and monitoring program are presented in Fig. 3. A full $50 \%$ of the eighteen plans made no reference to SCMs. Only one plan (\#18) prepared SCMs at the planning phase but did not declare intent to use and refine them until a future date. Two additional plans (\#14, \#15) prepared a single sample or framework SCM for use in preparing future species-specific SCMs. Six plans declared an intent to develop and use SCMs in their adaptive management and monitoring chapters (\#8, \#10,\#11, \#12, \#13, \#17). Significantly, eight of these nine collective plans referencing SCMs represent the plans in Table 2 subject to approval through the NCCP Act of 2003, which added the requirement for an adaptive management and monitoring component.

Beginning with a 2000 amendment to the NCCP Act, new NCCPs were also required to incorporate independent scientific input, although several plans already underway with signed Planning Agreements were "grandfathered" in and exempted from this requirement. A search of scientific advisory reports prepared at the start of the planning process for each NCCP required to prepare such an analysis (Table 2) revealed that seven out of 


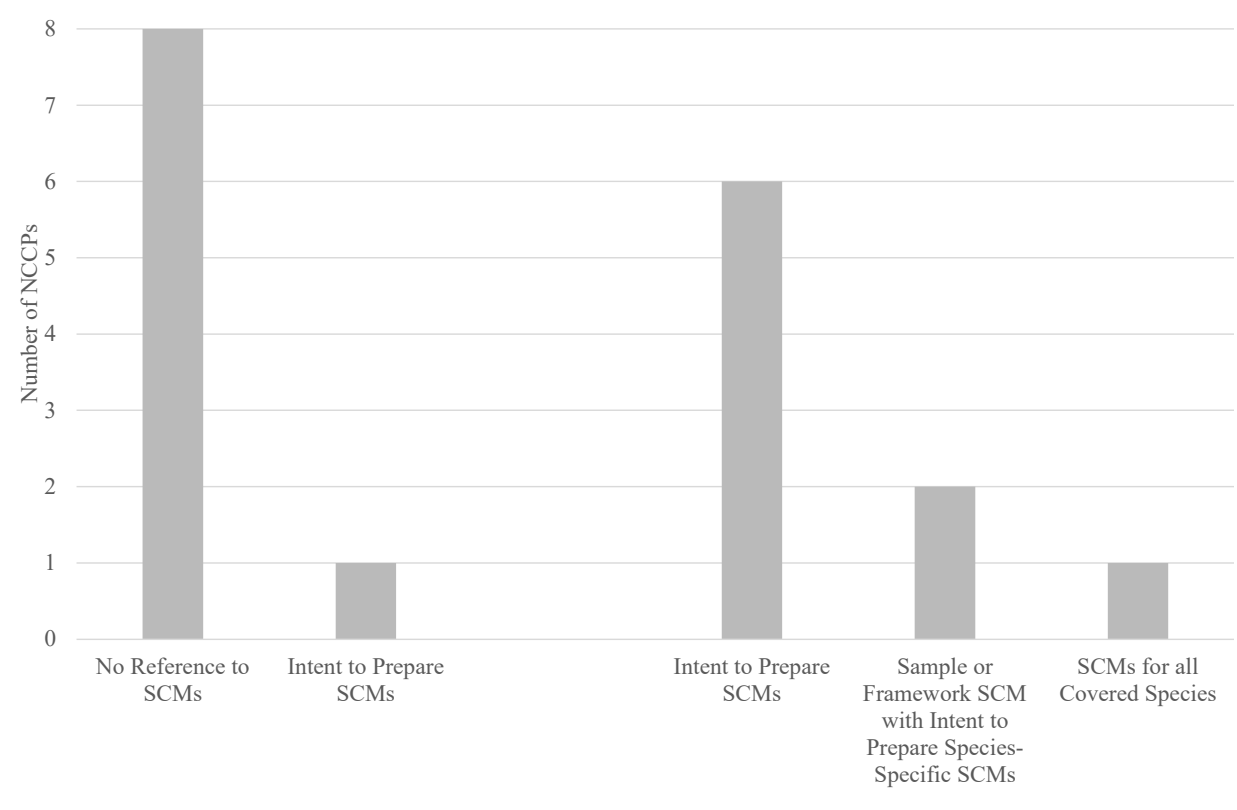

NCCPs Subject to 1991 or 2001

NCCPs Subject to 2003 Statute

Figure 3. Among early NCCPs ( $n=9$ ), only a portion reference species conceptual models ( $\mathrm{SCMs}$ ) in their adaptive management and monitoring chapters. Among NCCPs subject to the 2003 statute $(n=9)$, most plans present an intent to prepare SCMs in the future.

eight recommended the use of SCMs in adaptive management and monitoring. One such report called for the development of SCMs ideally up front, that is, in the planning phase (Rahn et al. 2008). It is worth noting that Atkinson et al. (2004) was published shortly after the NCCP Act of 2003, placing SCMs as necessary inputs to the adaptive management and monitoring process (Fig. 1).

Results of the search for connections between threats described in SAMs and biological goals and objectives are shown in Fig. 4, categorized and presented in order from least to most explicit connections. Six of the eighteen plans, or one-third, either made no direct reference or a very general one to the SAMS when presenting biological goals and objectives, indicating they were used but unclear about how. Two-thirds of the plans made direct references to SAMS in species-specific biological goals and objectives. The most explicit connections were made by eight plans (\#5, \#6, \#7, \#8, \#9, \#12, \#16, \#17), who chose to present an analysis of SAM components, such as threats, side-by-side with species-specific biological goals and objectives as a justification for them. Thus, it was transparent and immediate to see how the models and model assumptions were used.

Finally, we examined explicit connections between SDMs and reserve designs. Each of the 17 plans that contained SDMs made a direct reference to their use in the conservation strategy, which includes reserve design, and the one remaining plan (\#4) made reference to text-based information in the SAMs it contained. However, it was not always explicit how SDMs and SAMs were used. Since modeled suitable habitat is used along with occurrence data as the basis for reserve acreage commitments by species, the next question to examine 


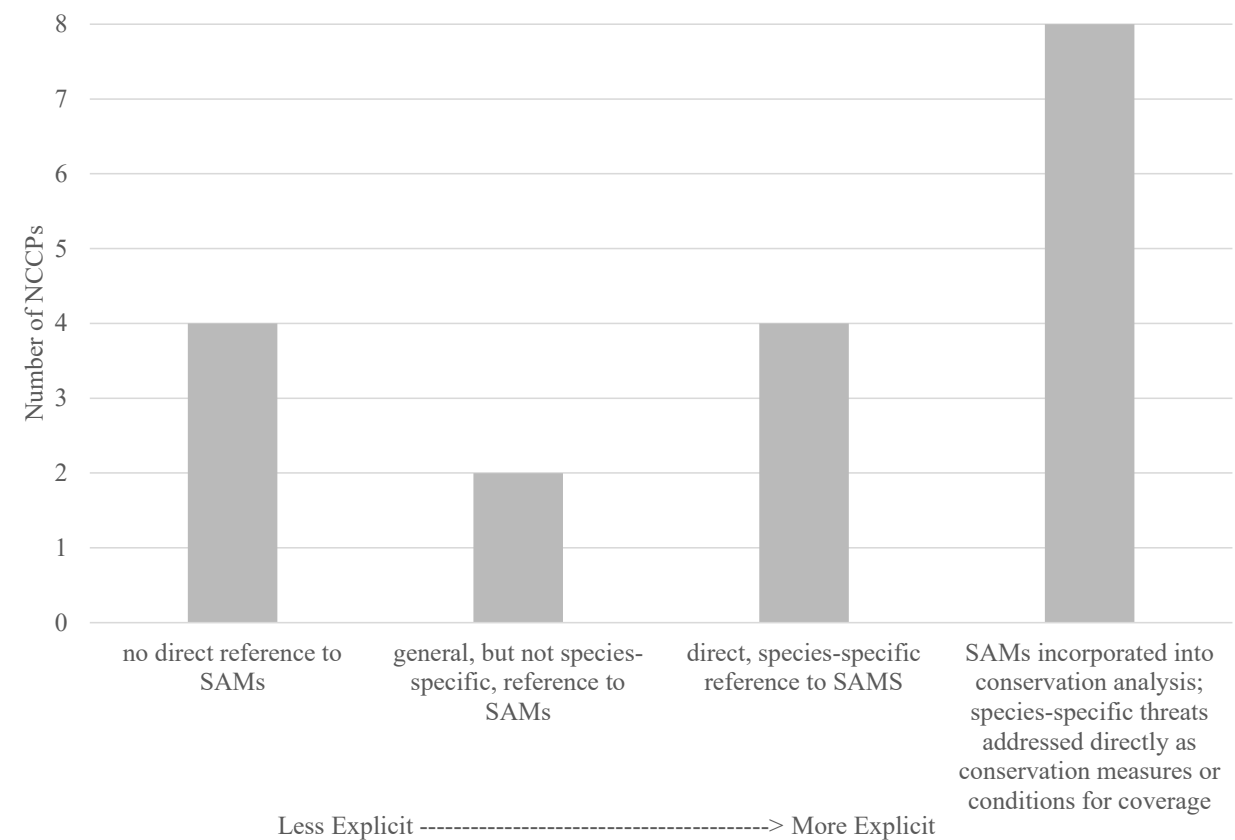

Figure 4. There is a range of explicitness among NCCPs in how SAMs connect to biological goals and objectives.

was how explicit the process was for using classified (expert opinion) suitable habitat in each SDM. The results are shown in Fig. 5. Of the 15 plans that had this SDM component, five plans (\#2, \#9, \#11,\#15,\#16) had habitats ranked as "high"/ "medium"/ "low" or "suitable"/ "unsuitable" for a species, without disclosing model inputs or assumptions, such as habitat types selected or minimum habitat patch size applied. Thus, these models could not be replicated just with the information contained in the plan. Ten plans were explicit about how each suitability map was created such that the process could be replicated in a GIS.

Regarding use of the models together in the creation of a reserve design, three levels have been distinguished and are shown in Figure 5 from the least to the most explicit. Three of the 17 plans containing at least one component of an SDM did not describe a process of using the models together in the reserve design (plans \#9, \#13,\#14). Four plans made reference to using SDMs in their reserve designs but were not explicit about how their individual SDMs may have been used together and upfront (plans \#10, \#15,\#17, \#18). Ten NCCPs described processes for using SDMs together and upfront for prioritizing lands in a reserve system (plans $\# 1, \# 15, \# 2, \# 3, \# 5, \# 6, \# 7, \# 8, \# 12, \# 16$ ). Spatial analysis methods used by the 10 plans included: (1) "hotspot" analyses, in which landscape data are divided into standard units such as square or hexagon grid cells and point-based species occurrence data is assessed for each cell to locate areas of high density or "hotspots," (2) formal and "informal" GAP analyses (USGS 2019), in which suitable habitat and/or known occurrences for one or more targeted species on a landscape is overlain with existing conserved lands to locate "gaps" in conservation, and (3) a composite habitat evaluation model (Ogden 1995), which consists of high priority habitat for selected covered species, wildlife corridor data, and a habitat value index. The habitat value index itself represents seven input data layers 


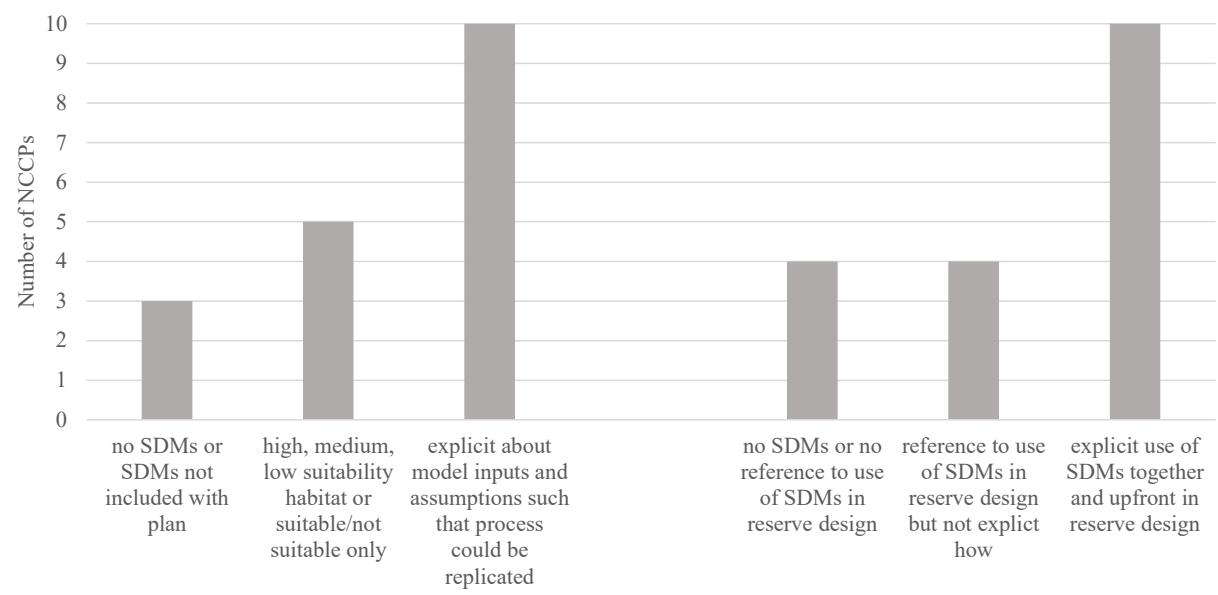

SDM Development

Use of SDMs Together in Reserve Design

Figure 5. In SDM development, not all NCCPs are explicit enough about model inputs such that the process can be replicated. In the use of SDMs together and upfront in reserve design, NCCPs vary in explicitness.

weighted and combined to assess relative biological value: soils known to support sensitive plant species, adverse edge effects, habitat element features (e.g., presence of cliffs, springs, or ponds), ecotone index, habitat diversity index, rarity of natural habitats, and potential to support covered species.

\section{DISCUSSION}

The results reveal that all plans create species models and reference them to some degree and most plans utilize SAMs in developing biological goals and objectives. Thus, there is a practice of connecting what is known about a species' life history, habitat use, geographic range, distribution, threats, and population trends to what would be appropriate objectives for that species in a strategy for conservation. Especially effective in conveying the reasoning behind a conservation strategy were those eight plans (44\%) that presented an analysis of SAM components, such as threats, side-by-side with species-specific biological goals and objectives as a justification for them.

What is most concerning is the almost non-existent use of SCMs in the planning phases of NCCPs. Only one plan developed SCMs up front, and even this plan did not utilize these models in developing a framework adaptive management and monitoring program. It is strongly recommended that plans develop and utilize SCMs up front, so these models can inform key components of the plan, as indicated in Figure 1 (Atkinson et al. 2004). As stated previously, SCMs are a bridge between the goals and objectives of a conservation plan and the conservation measures or management actions assumed necessary for achieving them. They also serve to identify priorities for monitoring and critical uncertainties that still need research (Atkinson et al. 2004), information that would be beneficial, especially when scoping the long-term cost of a plan. Franklin et al. (2011), in prefacing a case study for developing a monitoring program for the San Diego Multiple Species Conservation Program (MSCP), acknowledge that conservation plan objectives can be set too broadly to identify monitor- 
ing priorities during plan development and that monitoring and management often require more resources than are acknowledged or even known at the planning stage. Without proper funding at the outset, effectiveness monitoring for an NCCP can be significantly delayed.

There may be any number of reasons for the underutilization of SCMs in the planning phase of an NCCP. One is simply a lack of specificity in the requirements of the NCCP Act related to adaptive management and monitoring. In approving an NCCP, the state must find that the plan "integrates adaptive management strategies that are periodically evaluated and modified based on the information from the monitoring program and other sources" (Section 2810(a)(2)) "contains a monitoring program" (Section 2810(a)(7)) and "contains an adaptive management program" (Section 2810(b)(8)). Author MP has worked as an agency scientist reviewing NCCPs and preparing findings, and has found that these chapters are often very brief, with some planners considering that to define a management and monitoring program at the planning stage before reserve lands are acquired would be premature.

Although it would be premature to write individual management plans, SCMs with explicit assumptions are key to developing a management and monitoring framework to guide management planning across an entire reserve system. Managers of individual reserves must be able to translate the goals and objectives of a conservation plan into a work plan for management and monitoring - over time, in the context of a reserve network, and in the face of uncertainty. SCMs clarify assumptions regarding a species' relationship to ecosystem components, stressors, and its response to potential management actions (Atkinson et al. 2004; Hopkins 2004). If SCMs were to be developed while a conservation plan was still being written, the goals of the plan might be specified in a way that makes management targets and monitoring objectives obvious (Franklin et al. 2011).

Explicit assumptions included as part of a SCM are especially important in an adaptive management context, which necessarily treats assumed causal relationships between modeled ecological variables as hypotheses (Woodward et al. 1999; Barrows et al. 2005; Franklin et al. 2011; Runge et al. 2011). Wrote one participant as feedback in a San Diego workshop designed to develop SCMs: “... the way this modeling process was done, identifying stressors and using available life history information was a good approach. I think we came up with some interim management methods/tasks that could be used immediately... to help protect occupied Hermes [a butterfly species] habitat from fire while we wait for research questions to be answered about dispersal and other unknowns." (Lewison et al. 2012)

Plans varied in describing the creation of SDMs and their use together and upfront in reserve design. In creating SDMs, the five plans that simply ranked habitats as "high"/ "medium"/ "low" or "suitable"/ "unsuitable" for a species, without disclosing model inputs or assumptions may indeed have engaged in an explicit modeling process among scientists without publishing details of the process in the plan, but this should be discouraged as a planning practice for NCCPs. More explicitness makes the planning process more transparent and inclusive to other stakeholders because interested parties are able to replicate the models and understand the assumptions made in using them. It is strongly recommended that metadata accompany each SDM. Ideally, it would include all input data sets, their sources, their limitations of use as described by their creators, and the assumptions modelers made in assembling them to create a SDM. Because knowledge of a species distribution is often coarse or incomplete, understanding data available and methodological choices used to create a model is key to its appropriate use (Sofaer et al. 2019).

When it comes to using SDMs together and upfront in reserve design, it is signifi- 
cant that two of the three plans that did not conduct such an analysis are led by regional authorities with the ability to commit their own lands to a reserve system, and this factor is what likely drove the initial design. Among the remaining fourteen plans, one might have expected more spatial analysis among newer plans, with greater GIS capacity and access to more spatial data layers than were available to planners in the 1990s, but there does not appear to be a trend related to the year of plan approval. Researchers have acknowledged the difficulty in selecting an appropriate modeling method for multiple species, known as an ensemble modeling strategy (Lin et al. 2018). It is significant that two thirds of plans employed an ensemble strategy upfront in reserve design. Once again, it is recommended that modelers disclose any assumptions made or data limitations noted in the process of compiling multiple SDMs. For example, several NCCPs employed a process similar to that of the California Department of Fish and Wildlife (CDFW) Areas of Conservation Emphasis (ACE II) - which includes indices of biological value by hexagonal unit across the state, derived from occurrence data and range maps of multiple species. The metadata for ACE II not only discloses reasoning for the unit (hexagon) and scale (hexagon size) of analysis chosen, it also acknowledges that values are influenced by the data (or lack of data) available for any given species in any given region of the state. Included with the data are recommendations for appropriate use (CDFW 2015).

The intent of this paper has been to understand current practice regarding the integration of species models in systematic conservation planning, with an aim to improve practice overall, rather than to highlight the shortcomings of any individual plan. With a powerful and far-reaching statute to guide them and only fifteen plans approved statewide, NCCPs are in many ways still experimenting with best practices. Early publications have taken the form of case studies (Pollak 2001, for example) or guidance documents with "lessons learned."

Universally, plans were strong in including detailed SAMS, while they varied in their ability to connect models directly to biological goals and objectives. Two-thirds of plans were explicit in SDM creation such that individual species models could be replicated in a GIS with the information provided in the plan and two-thirds of plans demonstrated ways that SDMs can be used together in reserve design. We found the greatest room for growth in the use of SCMs for adaptive management and monitoring planning, which may be facilitated by more detailed requirements in statute regarding the adaptive management and monitoring component of a plan. Professional training in the creation and use of SCMs may also help. To this end, NCCPs in the implementation phase that have developed SCMs for monitoring would be an ideal resource.

\section{LITERATURE CITED}

Andelman, S. J., S. Beissinger, J. F. Cochrane, L. Gerber, P. Gomez-Priego, C. Groves, J. Haufler, R. Holthausen, D. Lee, L. Maguire, B. Noon, K. Ralls, and H. Regan. 2001. Scientific standards for conducting viability assessments under the National Forest Management Act: report and recommendations of the NCEAS Working Group. National Center for Ecological Analysis and Synthesis, Santa Barbara, CA, USA.

Andrewartha, H. C., and L. C. Birch. 1984. The Ecological Web. University of Chicago Press, Chicago, Illinois, USA.

Atkinson, A. J., P. C. Trenham, R. N. Fisher, S. A. Hathaway, B. S. Johnson, S. G. Torres, and Y. C. Moore. 2004. Designing Monitoring Programs in an Adaptive Manage- 
ment Context for Regional Multiple Species Conservation Plans. U.S. Geological Survey, Western Ecological Research Center. Sacramento, California, USA.

Barrows, C. W., M. B. Swartz, W. L. Hodges, M. F. Allen, J. T. Rotenberry, B. L. Li, T. A. Scott and X. W. Chen. 2005. A framework for monitoring multiple-species conservation plans. Journal of Wildlife Management 69:1333-1345.

Brussard, P., F. Davis, J. Medieros, B. Pavlik, and D. Sada. 2004. Report of the Science Advisors for the Placer County Natural Communities Conservation Plan and Habitat Conservation Plan: planning principles, uncertainties, and management recommendations. Available from: https://wildlife.ca.gov/Conservation/Planning/NCCP/Scientific-Input Butte Regional Conservation Plan. 2019. Available from: http://www.buttehcp.com/BRCP-Documents/Final-BRCP

California Department of Fish and Wildlife (CDFW). 2015. Areas of Conservation Emphasis

(ACE II) Project Report (v2). Biogeographic Data Branch, Sacramento, CA, USA.

Chang, K. 2019. Introduction to Geographic Information Systems. 9th Edition. McGraw Hill, New York, NY, USA.

City of Chula Vista. 2003. MSCP Subarea Plan. Available from: https://www.chulavistaca. gov/departments/development-services/planning/habitat-conservation

City of La Mesa. 1998. Subarea Habitat Conservation Plan / Natural Community Conservation Plan. Available from: https://nrm.dfg.ca.gov/FileHandler. ashx?DocumentID=35090\&inline

City of San Diego. 1997. MSCP Subarea Plan. Available from: https:/www.sandiego.gov/ planning/programs/mscp/docsmaps

Coachella Valley Multiple Species Habitat Conservation Plan (MSHCP). 2008. Available from: https://cvmshcp.org/Plan_Documents.htm

County of Orange Central and Coastal Subregion. 1996. Natural Community Conservation Plan/Habitat Conservation Plan. Available from: https://occonservation.org/ about-ncc

East Contra Costa County. 2007. Habitat Conservation Plan and Natural Community Conservation Plan. Available from: https:/www.contracosta.ca.gov/depart/cd/water/ HCP/archive/final-hcp-rev/final_hcp_nccp.html

Franklin, J. A. 2009. Mapping Species Distributions: Spatial Inference and Prediction. Cambridge University Press, Cambridge, NY, USA.

Franklin, J., H. M. Regan, L. A. Hierl, D. H. Deutschman, B. S. Johnson, and C. S. Winchell. 2011. Planning, implementing, and monitoring multiple-species habitat conservation plans. American Journal of Botany 98:559-571.

Greco, S. E. 2020. Assessing range-wide "contribution to recovery" by multiple local governments for a threatened species. Ecology and Society 25(3):13.

Guisan, A., R. Tingley, J. B. Baumgartner, I. Naujokaitis-Lewis, P. R. Sutcliffe, A. I. T. Tulloch, T. J. Regan, L. Brotons, E. McDonald-Madden, C. Mantyka-Pringle, T. G. Martin, J. R. Rhodes, R. Maggini, S. A. Setterfield, J. Elith, M. W. Schwartz, B. A. Wintle, O. Broennimann, M. Austin, S. Ferrier, M. R. Kearney, H. P. Possingham, and Y. M. Buckley. 2013. Predicting species distributions for conservation decisions. Ecology Letters 16:1424-1435.

Hopkins J. 2004. Regional conservation planning in California: a guide. Institute for Ecological Health, Davis, CA, USA. Available from: http://conservationplanning. 
info/wp-content/uploads/2019/03/CPGUIDE.pdf

Huntsinger, L.H. (chair), B. Errter, A. Launer, S. Orloff, B. Pavlik, S. Terrill, and E. Fleishman (facilitator). 2003. Science Advisory Panel Guidance for the East Contra Costa County Habitat Conservation Plan/Natural Community Conservation Plan Compiled During Four Meetings, May 2002-December 2003. Available from: https://wildlife.ca.gov/Conservation/Planning/NCCP/Scientific-Input

James, F. C., C. A. Hess, and D. Kufrin. 1997. Species-centered environmental analysis: indirect effects of fire history on red-cockaded woodpeckers. Ecological Applications 7:118-129.

Kern Water Bank Authority. 1997. Habitat Conservation Plan/Natural Community Conservation Plan. Available from: http://www.kwb.org/index.cfm/fuseaction/Pages. Page/id/491

Lewison, R. L., D. H. Deutschman, E. Marnocha, C. Tredick, and P. McIntyre. 2012. Developing conceptual models: translating knowledge into action: building and implementing an integrated framework for monitoring and management in San Diego County. Proceedings from a workshop held 29 February 2012, Mission Trails Regional Park. Prepared for the San Diego Association of Governments by the Institute for Ecological Monitoring and Management, San Diego State University, CA, USA.

Lin, Y., W. Lin, J. Anthony, T. Ding, J. Mihoub, K. Henle, and D. S. Schmeller. 2018. Assessing uncertainty and performance of ensemble conservation planning strategies. Landscape and Urban Planning 169:57-69.

Mair, L., A. C. Mill, P. A. Robertson, S. P. Rushton, M. D. F. Shirley, J. P. Rodriguez, and P. J. K. McGowan. 2018. The contribution of scientific research to conservation planning. Biological Conservation 223:82-96.

Margules, C. R., and R. L. Pressey. 2000. Systematic conservation planning. Nature 405:243-253.

Morris, W. M., D. Doak, M. Groom, P. Kareiva, J. Fieberg, L. Gerber, P. Murphy, and D. Thompson. 1999. A Practical Handbook for Population Viability Analysis. The Nature Conservancy, Arlington, VA, USA.

Natural Community Conservation Planning Act (NCCPA). 2003. 2001. 1991. California Fish and Game Code. Section 2800 et seq. California Department of Fish and Wildlife, Sacramento, CA, USA.

Noss, R. (editor), E. Allen, G. Balmer, J. Diffendorfer, M. Soule, R. Tracy, R. Webb, and M. O’Connell (facilitator). 2001. Independent Science Advisors Review: Coachella Valley Multiple Species Habitat Conservation Plan/Natural Communities Conservation Plan (MSHCP/NCCP). Available from: https://wildlife.ca.gov/Conservation/Planning/NCCP/Scientific-Input

Noss, R. F., M. A. O’Connell, and D. D. Murphy. 1997. The science of conservation planning: habitat conservation under the Endangered Species Act. Island Press, Covelo, California, USA.

Orange County Transportation Authority (OCTA). 2016. M2 Natural Community Conservation Plan / Habitat Conservation Plan. Available from: https:/www.octa.net/ About-OC-Go/OC-Go-Environmental-Programs/Preserve-Management/

Ogden Environmental and Energy Services Co., Inc. (Ogden). 1995. Volume II: Multiple Species Conservation Program. Appendix A-10. GIS Habitat Evaluation Model. 
Placer County Conservation Program. 2018. Western Placer County Conservation Plan Habitat Conservation Plan/Natural Community Conservation Plan. Available from: https://www.placer.ca.gov/3362/Placer-County-Conservation-Program

Pollak, D. 2001. Natural Community Conservation Planning (NCCP): the origins of an ambitious experiment to protect ecosystems. Part I of series. California Research Bureau. Sacramento, CA, USA. Available from: https://nrm.dfg.ca.gov/FileHandler.ashx?DocumentID $=6388 \&$ inline

Poway Subarea Habitat Conservation Plan/Natural Community Conservation Plan. 1996. Available from: https://www.poway.org/323/Planning-Reference-Documents

Presley, G. L. 2011. California's Natural Community Conservation Program: saving species habitat amid rising development. Pages $115-145$ in K. Arha and B. H. Thompson, editors. The Endangered Species Act and Federalism: Effective Conservation through Greater State Commitment. Routledge, New York, NY, USA.

Rahn, M. (lead science advisor), P. Bowler (advisor), K. Preston (advisor), T. Smith (advisor), and B. DiGennaro (facilitator). 2011. Independent Science Advisors Report. Orange County Transportation Authority M2 NCCP/HCP. Available from: https://wildlife.ca.gov/Conservation/Planning/NCCP/Scientific-Input

Rahn, M. (lead advisor), D. Faulkner, M. A. Hawke, B. Hollingsworth, P. Unitt, and D. Zippin and K. Mozumbder (facilitators). 2008. San Diego County Water Authority NCCP/HCP Report of Independent Science Advisors. Available from: https:// wildlife.ca.gov/Conservation/Planning/NCCP/Scientific-Input

Rancho Palos Verdes. 2018. Final Draft Natural Community Conservation Plan and Habitat Conservation Plan. Available from: https://www.rpvca.gov/490/Palos-VerdesNature-Preserve-NCCP-PUMP-H

Runge, M. C., S. J. Converse, and J. E. Lyons. 2011. Which uncertainty? Using expert elicitation and expected value of information to design an adaptive program. Biological Conservation 144:1214-1223.

San Diego County. 2011. Water Authority Subregional Natural Community Conservation Plan/Habitat Conservation Plan (NCCP/HCP). Available from: https://www.sdcwa.org/natural-community-conservation-plan-habitat-conservation-plan

San Diego Gas \& Electric Company Subregional Conservation Plan. 1995. Available from: https://nrm.dfg.ca.gov/FileHandler.ashx?DocumentID=115861\&inline

San Diego Final MHCP Plan for the Cities of Carlsbad, Encinitas, Escondido, Oceanside, San Marcos, Solana Beach and Vista. Volumes I, II, and III. 2003. Available from: https://www.sandag.org/index.asp?projectid=97\&fuseaction=projects.detail

San Diego Final Multiple Species Conservation Program MSCP Plan. 1998. Available

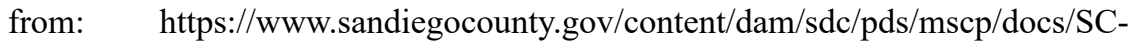
MSCP/FinalMSCPProgramPlan.pdf

Santa Clara Valley Habitat Plan. 2012. Available from: http:/scv-habitatagency.org/178/ Santa-Clara-Valley-Habitat-Plan

Sofaer, H. R., C. S. Jarnevich, I. S. Pearse, R. L. Smyth, S. Auer, G. L. Cook, T. C. Edwards, Jr, G. F. Guala, T. G. Howard, J. T. Morisette, and H. Hamilton. 2019. Development and delivery of species distribution models to inform decisionmaking. BioScience 69:544-557.

Spencer, W. D., S. J. Barry, S. R. Beissinger, J. L. Florsheim, S. Harrison, K. A. Rose, J. J. Smith, and R. R. White. 2006a. Report of Independent Science Advisors for Santa 
Clara Valley Habitat Conservation Plan/Natural Community Conservation Plan (HCP/NCCP). Conservation Biology Institute. Available from: https://wildlife. ca.gov/Conservation/Planning/NCCP/Scientific-Input

Spencer, W., R. Bogiatto, S. Collinge, T. Engstrom, G. Geupel, L. Huntsinger, M. Marchetti, J. Marty, M. Schwartz, and J. Piovia-Scott (assistant). 2007. Report of Independent Science Advisors for Butte County Habitat Conservation Plan/Natural Community Conservation Plan ( $\mathrm{HCP} / \mathrm{NCCP})$. Conservation Biology Institute. Available from: https://wildlife.ca.gov/Conservation/Planning/NCCP/ScientificInput

Spencer, W. (lead advisor/facilitator), R. Noss, J. Marty, M. Schwartz, E. Soderstrom, P. Bloom, G. Wylie, and S. Gregory (contributor). 2006b. Report of Independent Science Advisors for Yolo County Natural Community Conservation Plan/Habitat Conservation Plan (NCCP/HCP). Available from: https://wildlife.ca.gov/Conservation/Planning/NCCP/Scientific-Input

Tulloch, A. I. T., P. Sutcliffe, I. Naujokaitis-Lewis, R. Tingley, L. Brotons, K. Ferraz, H. Possingham, A. Guisan, and J. R. Rhodes. 2016. Conservation planners tend to ignore improved accuracy of modelled species distributions to focus on multiple threats and ecological processes. Biological Conservation 199:157-171.

Underwood, J. G. 2010. Combining landscape-level conservation planning and biodiversity offset programs: a case study. Environmental Management 47:121-127.

U.S. Fish and Wildlife Service (USFWS). 2007. Findings and Recommendations for the Issuance of Section 10(a)(1)(B) Incidental Take Permits Associated with the East Contra Costa County Habitat Conservation Plan/Natural Community Conservation Plan. Available from: https://www.contracosta.ca.gov/depart/cd/water/HCP/ documents/USFWS_Findings_and_Recommendation_for_Section10a1B_permit.pdf

U.S. Geological Survey (USGS). 2019. The GAP Analysis Process and Importance. https:// www.usgs.gov/core-science-systems/science-analytics-and-synthesis/gap/science/gap-analysis-process-and-importance?qt-science_center_objects=0\#qt-science center_objects

Western Riverside Multi-Species Habitat Conservation Plan (MSHCP). 2003. Available from: https://www.wrc-rca.org/about-rca/multiple-species-habitat-conservationplan/

Woodward, A. K., A. J. Jenkins, and E. G. Schreiner. 1999. The role of ecological theory in long-term ecological monitoring: report on a workshop. Natural Areas Journal 19:223-233.

Yolo Habitat Conservation Plan/Natural Community Conservation Plan. 2018. Available from: https://www.yolohabitatconservancy.org/documents

Submitted 1 February 2021

Accepted 16 March 2021

Associate Editor was M. Mantor 